Chapman University

Chapman University Digital Commons

Education Faculty Articles and Research

Attallah College of Educational Studies

4-2-2013

\title{
Chieftaincy-Based Community Dispute Resolution: The Case of Sierra Leone
}

Whitney McIntyre Miller

Chapman University, wmcintyr@chapman.edu

Follow this and additional works at: https://digitalcommons.chapman.edu/education_articles

Part of the African Studies Commons, Civic and Community Engagement Commons, Community-Based Research Commons, Family, Life Course, and Society Commons, Interpersonal and Small Group Communication Commons, Leadership Studies Commons, Models and Methods Commons, Other Communication Commons, Other Political Science Commons, and the Social Influence and Political Communication Commons

\section{Recommended Citation}

McIntyre Miller, W. (2013), Chieftaincy-Based Community Dispute Resolution: The Case of Sierra Leone. Conflict Resolution Quarterly, 30: 295-308. doi: 10.1002/crq.21066

This Article is brought to you for free and open access by the Attallah College of Educational Studies at Chapman University Digital Commons. It has been accepted for inclusion in Education Faculty Articles and Research by an authorized administrator of Chapman University Digital Commons. For more information, please contact laughtin@chapman.edu. 


\section{Chieftaincy-Based Community Dispute Resolution: The Case of Sierra Leone}

\section{Comments}

This is the accepted version of the following article:

McIntyre Miller, W. (2013), Chieftaincy-Based Community Dispute Resolution: The Case of Sierra Leone. Conflict Resolution Quarterly, 30: 295-308. doi: 10.1002/crq.21066

which has been published in final form at DOI: 10.1002/crq.21066. This article may be used for noncommercial purposes in accordance with Wiley Terms and Conditions for Self-Archiving.

\section{Copyright}

Wiley Periodicals, Inc., and the Association for Conflict Resolution 


\title{
Chieftaincy-based Community Dispute Resolution: The Case of Sierra Leone
}

\author{
Abstract \\ Sierra Leone suffered a destructive eleven-year civil war that largely left its communities \\ torn apart and in need of vast redevelopment. One of the ways that communities are rebuilding \\ and making efforts to move forward is through the chieftaincy-based community dispute \\ resolution process. Based on historical norms, this process involves the community leader, or \\ chief, helping to resolve disputes within the community. This article reviews this chieftaincy- \\ based community dispute resolution process, discusses the types of disputes settled, and provides \\ broader lessons learned for communities who may be interested in truly community-based \\ dispute resolution.
}

\section{Introduction}

Communities all over the world struggle to find a way to come together and grow stronger. In some parts of the world this is a process of finding mutual goals and interests and striving to accomplish those. In others, it is recovering from a civil war that ripped apart communities and left society in disarray. Despite the wide spectrum, each type of community sees their own form of disputes and challenges. This article addresses how two communities in Sierra Leone are using a chieftaincy-based community dispute resolution process to help solve local-level disputes to ensure that the community can come together and focus on growing strong and building lasting peace.

\section{Sierra Leone Civil War and Study Methodology}

Sierra Leone was wracked by civil war and strife during an eleven year conflict between 1991 and 2002. The rebel group the Revolutionary United Front, backed by the infamous Charles Taylor, ripped through communities burning villages, raping and amputating civilians, 
and attempting to claim power in the country after years of corruption and failed governments (Abraham, 2001; Keen, 2005). At the close of the war, of the 4.7 million citizens, an estimated 50,000-70,000 Sierra Leoneans were dead, 2.6 million were refugees, and 1.2 million were internally displaced persons (Masin-Peters, 2003; Pham, 2006; Writenet, 1997).

The country was left in great physical, social, and economic disarray as the result of the war and redevelopment work was needed both in the local communities and across the nation. Much of the country was without infrastructure, including a road network, electricity, a formal education system, and running water. Local chiefs, along with their community members, were often killed or had fled during the conflict, leaving communities without leadership and limited residents. The government, while reestablished, was left with many development tasks and little money and expertise to begin implementation of a redevelopment plan. In fact, the government was largely reliant on active international peace-building organizations to finance over half of its budget (Baker, 2006; Baker \& May, 2006; Freeman, 2008).

It was under this enormous pressure that the country began to rebuild. Many projects were addressed in the years following the war by a large number of international, national, and local organizations and efforts. In 2009, an over-arching five-week in-country qualitative grounded theory study was conducted to understand redevelopment at the community level. This study, which included interviews of 28 community members from two communities in the Northern provinces (all names cited herein are pseudonyms), participation in events and meetings, and general community observations, addressed community-based redevelopment on a broad scale. It included understanding the role of international organizations, the government, and local-based efforts in community building. 
This overall research demonstrated that there were many factors at play in postconflict community development in Sierra Leone (for full analysis see: McIntyre Miller, 2012). Among these factors discussed were conflict and dispute resolution and reconciliation practices. In Sierra Leone, as with many postconflict countries, there has been a good deal of research on the more formalized ritual reconciliation processes and Truth and Reconciliation commissions (Ferme, 2001; Kelsall, 2005; Mundy, 2005; Parringer, 1976). These have made valuable contributions to resolving broad issues of the war, but were often unable to fully grasp local needs of healing and moving forward after the war (Millar, 2011). This article, therefore, aims to break away from these more common modes of reconciliation to address a local means to dispute resolution that had a great impact on building community and bringing people together: the practice of chieftaincy-based community dispute resolution.

\section{Overview of the Chieftaincy and Role in Dispute Resolution}

The Sierra Leone chieftaincy was established by British colonialists; although a loose structure existed prior to colonization (Peake, Gormley-Heenan, and Fitzduff, 2004; Sawyer, 2008). The institution of the chieftaincy was meant to serve as a way to limit governance by the colonialists (Jackson, 2005; Peake et al., 2004). Chiefs ruled for a lifetime based on issues of inheritance and paternal lineage (Fanthorpe, 2003; Keen, 2003, 2005). They represented the local people to the government, levied taxes and other fines as needed, ran the local court systems, and were given the power to bestow rights on both the occupants of their land and their descendants (Fanthorpe, 2001, 2003; Jackson, 2005; Keen, 2005; National Recovery Committee, 2002; Richards et al., 2004; Sawyer, 2008). Prior to the war, this power over citizens and local monies could lead to the corruption of some of the chiefs (Keen, 2003, 2005; Peake et al., 2004; Sawyer, 2008; Thomson, 2007). It was this corruption and misuse of power that contributed to 
an alienation of the youth in the communities, resulting in some of them siding with the rebel movement in their bid for control of the country (Jackson, 2005; Thomson, 2007). It is important to note, therefore, that the behavior of some of the chiefs directly contributed to the outbreak of the conflict.

This history of corruption led to an interesting dilemma at the conclusion of the war. Several researchers challenged the effectiveness of maintaining the chieftaincy system in Sierra Leone due to the pre-war abuses (Fanthorpe, 2005; King, 2005; Richards, 2005; Sawyer, 2008; Thomson, 2007). The local people, however, were said to return to their communities after the war because they knew if the chiefs had returned, they could provide them with a sense of safety and security and play a role in development and conflict resolution (King, 2005; Sawyer, 2008; Thomson, 2007). The chiefs were seen as "the most effective conflict resolution in Sierra Leone” and especially important for settling disputes in the rural areas where direct contact was more likely (Sawyer, 2008, p.394). The chiefs of these rural areas would often settle the day-today disputes in village meetings or in their compounds (Archibald \& Richards, 2002), making the process very community-oriented.

The important role the chiefs played in dispute resolution, among other issues, demonstrated the value of maintaining the chieftaincy despite past corruption. In order to avoid some of the pitfalls of the past, however, a government-run local court system was established after the war. This court system enhanced the decision-making of chiefs around issues focused on families, debts, inheritance, and land (Baker \& May, 2006; Fanthorpe, 2004; Glentworth, 2002). Providing this system was a challenge, though, because national laws were in need of updating; the courts were highly expensive for the local people; and there was a lack of qualified personnel to handle legal matters and be the judges and magistrates, due the high number of 
qualified personnel who fled during the war (Glentworth, 2002; International Crisis Group, 2003). In fact, despite the court system, still an estimated $80 \%$ of disputes were still settled through the chiefs (Hanlon, 2005).

\section{Research Findings}

The research findings around the chieftaincy-based community dispute resolution process described in this next section help to augment what was already known from the literature. In addition, it serves to provide a greater understanding of the types of disputes that were settled and the role of the chief in these settlements. This findings section details the process of chieftaincy-based community dispute resolution in the two communities studied.

Chieftaincy-based community dispute resolutions occurred once a conflict had escalated to the point where the individuals or groups involved believed they could no longer resolve those disputes themselves. "Petty quarrels [are] like ripples in a pond when you throw a stone in" (Florence, interview with author, Sierra Leone, June 9, 2009). Even a small stone could send waves through the whole community shaking it to its core. Many felt there was great importance in keeping the community peaceful if overarching peace was to take hold.

While the chiefs may not be able to address the underlying issues or root causes of the disputes, they assisted in providing a form of arbitration. According to an elder, Ishmael (interview with author, Sierra Leone, May 29, 2009), “when domestic clashes occur [community members] can take the report to the chief and he amends it.” Rosaline (interview with author, Sierra Leone, June 2, 2009), a community leader, added that the chiefs "intervene ... and make compromises ... and get people together.” Overall, the chiefs were seen as settling disputes with both fairness and thoughtfulness. One community member stated that "the chief [was] very truthful” (Miatta, interview with author, Sierra Leone, June 5, 2009), and another stated that 
“[the chief] tries hard to settle [disputes] well” (Arif, interview with author, Sierra Leone, June 7, 2009).

\section{Land Use Disputes}

Disputes within the community tended to stem from two major issues, those related to land use issues and those centered on social conflicts. Land cases were most often discussed as they directly affected the land on which the community members lived and the shared community spaces. Building community cohesion and peace was seen as challenging when community members were fighting over their right to land, or worried about the possibility of their land being taken away. It was for this reason that settling land disputes appeared to be of particular interest to many community members interviewed.

Most often, land disputes centered around on two issues. The first was a conflict between families about rights to land. The second were disputes about land use for international organizations’ local operations.

Land disputes would frequently arise in an individual or a group’s efforts to gain resources. As land was often some of the only property that an individual or family owned, taking the opportunity to sell that land could be profitable. The disputes tended to arise when the family failed to agree to the sale of the land. In a number of instances, some family members would try to sell the land without the others' knowing, and thus only share the profits with those involved in the sale. Since many members of the same family live on the same land in Sierra Leone, those family members not involved in the sale would lose their homes.

Other conflicts arose, according to Florence (interview with author, Sierra Leone, June 9, 2009), a community leader, because when 
... someone dies there can be a distribution problem. Women are not allowed to own land so this can cause a problem too. If a man dies his brother can try to take the land from the widow and the children. Now there are rules for them to share, but people get in disputes over houses, property, and land.

In some instances, these land disputes could get out of hand. According to Alie (interview with author, Sierra Leone, June 6, 2009), a mechanic, these land disputes "within and between families ... [could] sometimes result in killing.” It was for this reason, that the chiefs played an important role in dispute resolution, in order to prevent those land disputes that divided Sierra Leonean families from having larger community consequences. It was not unusual, even in less extreme cases, for the community members to take sides, sometimes by offering assistance to those who no longer had a place to live. The chiefs were seen as mediating these land disputes by making compromises between the two disputants thus helping to minimize the community damage (Rosaline, interview with author, Sierra Leone, June 2, 2009).

Land disputes would also arise over the selling of land to international organizations operating local development projects within the community. Sometimes these organizations did not understand that in order to procure community land, they must go through the chief. According to Zaria (interview with author, Sierra Leone, June 5, 2009), a community leader, "When development [was] coming, the Chief [gave] land for [the organizations] to improve the town.” International organizations that were unfamiliar with these cultural norms sometimes purchased land from those who did not have the right to sell that land. In some instances the individual or group might not have the permission from the family to sell the land, or might convince the organization to buy land that was not actually owned by the seller. When this occurred, those selling the land would receive money for land that was either not wholly or even 
partly theirs to sell. Similar to general land cases, this could cause great upheaval and confusion in the community. The chief was then called in to settle the dispute so that both the rightful land owners and the international organizations could find an agreeable solution.

\section{Social Issues Disputes}

The chiefs also often mediated disputes around social issues, including disputes related to stealing, promiscuity and polygamy, and general discontent. Mechanic Alie (interview with author, Sierra Leone, June 6, 2009), and others, believed that these disputes were also "tear[ing] the community apart," as each of these disputed issues had the potential of causing riffs in the community. It was important, therefore, that the chiefs' assist in settling these disputes because they were seen as being able to "build peace between [disputants, since] the chief is concerned with the welfare of the people...” (Zaria, interview with author, Sierra Leone, June 5, 2009).

Community members believed that settling matters of stealing were particularly important for the chiefs because these disputes were visual- people were able to see their property in another's possession, which could easily create community divisions. The chiefs played a role in stealing disputes both immediately after the war and in an ongoing fashion. During the war, the rebels often stole the local people's goods, so when the war ended, the chiefs' were responsible for determining to whom the goods belonged. Stealing after the war consisted largely of the theft of personal items, such as chickens and goats. Oftentimes those without work were blamed for the stealing occurrences. After the war it was difficult for many to find employment. In fact, as of 2010, the unemployment rate in the country was 70\% (Murray \& McKague, 2010).

A story of theft was shared by a tailor in one of the communities. He had his tailoring shop broken into and all of his machines stolen; he lost his ability to conduct business (Mark, 
interview with author, Sierra Leone, June 8, 2009). This made him and others distrustful, which hindered community cohesion. The chiefs' assistance in generating a compromise about stolen items attempted to create a balance again within the community.

The chiefs also helped to settle disputes around issues of promiscuous and polygamous behavior. During the war a culture of lax sexual behavior had formed due to both rebel activity, and the behavior of some of the international peace keeping forces. This led to what the local people classified as promiscuity after the war. There were violations of marriage contracts and familial bonds and sex out of wedlock, which could cause disputes within and among families.

Disputes also arose due to polygamy, even though this was a traditional practice in Sierra Leone. According to Mark (interview with author, Sierra Leone, June 8, 2009), "Polygamy tears people apart. [The husband] likes the last wife better than the first wife and this causes problems. The husband treats the three wives and children different than the last wife and children.” It was apparent that disputes sexual in nature were equally harmful to community’s dynamics, which is why the chiefs were called upon to assist in their settlement.

A third type of social issue dispute the chiefs assisted in settling was related to dishonesty and misrepresentation. These types of disputes tended to arise from false gossip and jealousy over jobs, access to jobs, and other successes. The chiefs were called upon to settle these types of disputes because "people [should not] judge... It is good when someone is doing a good job because he is working hard and is doing well, which in turn helps the community, so people should not have hatred towards him” (Karamoh, interview with author, Sierra Leone, May 30, 2009). The divide between those who were successful and those who were not, or misrepresentation of this success, would cause a rift in the community. The chiefs would be 
called in to settle these disputes and resolve these accusations to help build community peace and understanding that advancement by one could mean advancement for all.

The final area where the chiefs were called upon to settle disputes was around issues of corruption. Instances of bribery were frowned upon, as it was reminiscent of the deceitful culture of corruption seen before the war in the communities and throughout the country. “Corruption [was] bad because if people [knew] you [were] grabbing for yourself, then the community [would] fall apart. This [was] making people unstable. Everyone [was] corrupt. Greed [was] a problem; people [were] trying to take everything for themselves” (Suzan, interview with author, Sierra Leone, June 4, 2009). It was important, then, for the chiefs to help settle disputes around bribery and corruption in an attempt to avoid some of the pitfalls seen in the country prior to the war.

Checks and Balances in Chieftaincy-based Community Dispute Resolution

Overall, community members were pleased with the role the chiefs played in dispute resolution. There was, however, some discussion of the chief's inability to fully settle disputes fairly. Some believed that the chiefs played favorites in their settlements. Sahr (interview with author, Sierra Leone, May 28, 2009), a community member who had been unhappy with settlements, believed that unfair dispute settlement "rip[ped] the community apart.”

In order to combat any unfair settlements, courts were put in place by the government as a forum for the local people to challenge disagreeable resolutions made by the chief. While these courts offered a way to challenge the rulings of the chiefs, they were often very expensive due to the lawyer and magistrate fees. This could heighten the divide between the rich and the poor, as only the richer community members could afford to take the case to court. In some instances, when the dispute was between a rich and poor community member and the case went 
to court, the rich disputant would win since the poor disputant could not afford representation and there was no government assistance offered to assist the poor disputant (Florence, interview with author, Sierra Leone, June 9, 2009).

Not only did money determine whether an individual could pay for council and the fees of the court, it also, in some cases, provided access to the magistrate. According to Florence (interview with author, Sierra Leone, June 9, 2009), a community leader, the tradition in Sierra Leone was to provide those with community power some sort of monetary token for their service to the community. Therefore, those with money would be able to provide such a token to the magistrates, where those without would be unable to do so. Consequently, many peoples’ limited resources discouraged just and equitable treatment in the court system. Those who could not afford to take cases to court had to rely on the settlement by the chief, whether or not they believed it to be just.

Taking cases to court, therefore, was often not feasible for the local people, which further enhanced their reliance on the chiefs to be fair. Several community members believed when cases went to court it made the chiefs look as though they were dishonest. This, they believed, served as additional encouragement for the chiefs to be fair in their settlements, although of course a fair settlement was never guaranteed.

\section{Discussion and Implications}

Overall, the community members believed that the chieftaincy-based community dispute resolution process was one that was beneficial to the community, especially in terms of postconflict development. The chiefs' role in helping to settle disputes provided a sense of comfort to the communities as they moved forward. The traditional nature of the chieftaincy and 
its role in dispute resolution helped people feel comfortable with the process, and the court system, despite its limitations, provided a sense of checks and balances.

The specific examples of disputes and processes outlined in this case can only truly demonstrate the particulars of the two communities studied. However, extrapolations to other types of communities and cultures can still be readily made. The first of these lessons is based around the involvement of the broader community in the dispute resolution process.

Disputes, and therefore their resolutions, are seen as a community endeavor in Sierra Leone. Any dispute does not just occur between the disputants, but has consequences throughout the community. The chieftaincy-based community dispute resolution process is designed to strengthen the ties within the community; therefore, this is not an isolated process involving only the disputants. In a very isolated western world, we tend to not share our problems and concerns with those around us and often do not think of the implications our conflicts have on others in our larger community.

In Sierra Leone, community connectedness is a key factor to maintaining a successful dispute resolution process. Although in the United States there are many cities with community dispute resolution centers, we see that these still focus on individual disputants and often do not involve or include the broader community in their process. While considering community implications and creating a sense of community as part of the dispute resolution process may be a challenge in many western communities, it would be beneficial to ponder how dispute resolution might serve to strengthen community ties. Perhaps disputes could be heard in a community forum, or disputants asked to discuss the implications of their dispute and its resolution on the broader community as a way to begin to reflect on dispute resolution as a community building concept. 
Seeing a single dispute as part of the broader picture of community connectedness and engagement is essential in Sierra Leone and could be quite beneficial in other societies. We must challenge ourselves to think of this connectedness in our dispute resolution processes. When we begin to see that disputes impact more than just the disputants, and we begin to connect our actions with community actions and reactions, we can grow. Having communities take up this practice may provide a way to build more peaceful community interactions in all communities not just those suffering from a debilitating war.

Another transferable concept learned from the case of chieftaincy-based community dispute resolution in Sierra Leone was the notion of a community leader heading dispute resolution. Various forms of community leadership can be seen in societies around the world, such as a chief, a mayor, or the head of a town council. Lessons from this study indicate that disputes may be settled by a third party of community power as long as they maintain trustworthiness. It is important to note the trustworthiness factor, as the chiefs were considered trustworthy for they provided the sense of security that community members needed to return home. Those who have community power, but do not have their community member's faith in them and their abilities, may find they have a difficult time mediating disputes and having their resolutions followed.

Of course this notion of having mayors or other community leaders resolve disputes in the community would likely be quite foreign to those in western societies, as we may most often look toward trained mediators to conduct third party dispute resolutions. In many ways, the chieftaincy-based community dispute resolution process is similar. There is greater weight, however, to the fact that the individual evaluating the debate is the community leader, which would more directly connect the dispute to the community. This model may not be feasible in 
many larger communities both in western society, and in some more indigenous-based societies, as in smaller, more rural communities. These smaller communities could be successful in this model if the community leader was trained in mediation and/or dispute resolution and could serve a similar role in dispute settlement as the chiefs in the Sierra Leonean communities. Community members would also have to be open to a new way of sharing disputes and learning to grow together through these disputes and their resolution as a community.

Another key lesson from the chieftaincy-based community dispute resolution process in Sierra Leone was the importance of checks and balances. Although the court system in Sierra Leone was not very accessible to community members, there was a mechanism in place to ensure that decisions made by the chief were fair, or that at least encouraged a fair resolution. This was done through cases actually being taken to court, or by the threat that such cases could be taken to court, which was seen as undermining the chief's credibility. Therefore, it is important that communities implementing a dispute resolution process conducted by the community leader also set up a system to ensure fair settlement. In many western communities this may already come in the form of the formalized legal and court system. Thus, disputants who are dissatisfied with the resolution can follow standard western procedural law.

Finally, it is important to note that the disputes seen in Sierra Leone may be quite different from the disputes seen in other communities around the world. While issues of gossip, misrepresentation, and theft may be common in many communities, land case issues and those of a sexual nature may not appear as relevant to other communities. An important lesson to learn from the disputes in Sierra Leone, and those in other communities, is that they are often connected to the community in integral ways. Just like in the case of Sierra Leone, community leaders involved in dispute resolution cannot likely address the root causes of these issues and 
disputes. Addressing them in a community forum, however, and providing a space for the community to learn from each other and to strengthen themselves as a result of these conflicts, could prove beneficial to many communities around the world.

\section{References}

Abraham, A. "Dancing with the Chameleon: Sierra Leone and the Elusive Quest for Peace.” Journal of Contemporary African Studies, 2001, 19 (2), 205-228.

Archibald, S., and Richards, P. "Converts to Human Rights? Popular Debate About War and Justice in Rural Central Sierra Leone.” Africa: Journal of the International African Institute 2002, 72(3) 339-367.

Baker, B. “Post-Settlement Governance Programmes: What is Being Built in Africa?” In O. Furley \& R. May (eds.), Ending Africa's wars: Progressing to peace. Hampshire, England: Ashgate Publishing Limited, 2006.

Baker, B., and May, R. “A Sustainable Peace? Sierra Leone.” In O. Furley \& R. May (eds.), Ending Africa's wars: Progressing to peace. Hampshire, England: Ashgate Publishing Limited, 2006.

Fanthorpe, R. “Neither Citizen nor Subject? 'Lumpen’ Agency and the Legacy of Native Administration in Sierra Leone.” African Affairs, 2001, 100(400), 363-386.

Fanthorpe, R. "Humanitarian Aid in Post-War Sierra Leone: The Politics of Moral Economy.” In S. Collinson (ed.), Power, Livelihoods and Conflict: Case Studies in Political Economy Analysis for Humanitarian Action. London, United Kingdom: Overseas Development Institute, 2003. 
Fanthorpe, R. Post-War Reconstruction in Rural Sierra Leone: What Political

Structures May Prove Viable? Sussex: UK Department for International Development, 2004.

Fanthorpe, R. "On the Limits of Liberal Peace: Chiefs and Democratic Decentralization in Post-“ War Sierra Leone.” African Affairs, 2005, 105(418), 27-49.

Ferme, M. C. The Underneath of Things. Berkeley, CA: The University of California Press, 2001.

Freeman, C. The failures of post-conflict reconstruction in Sierra Leone and the threat to peace. Beyond Intractability . 2008. Retrieved from: http://www.beyondintractability.org/ case_studies/reconstruction_sierra_leone.jsp?nid=6811

Glentworth, G. Post-Conflict Reconstruction: Key Issues in Governance. A Preliminary Discussion Paper. 2002. Retrieved from the United Kingdom Department for International Development website: http://www.gsdrc.org/docs/open/SS13.pdf

Hanlon, J. "Is the International Community Helping to Recreate the Pre-Conditions for War in Sierra Leone?” The Round Table: The Commonwealth Journal of International Affairs, 2005, 94(381) 459-472.

International Crisis Group. Sierra Leone: The state of security and governance. 2003. Retrieved from http://www.crisisgroup.org/home/index.cfm?id=1492\&l=1

Jackson, P. “Chiefs, Money and Politicians: Rebuilding Local Government in Post-War Sierra Leone.” Public Administration Development, 2005, 25(1), 49-58.

Keen, D. “Greedy Elites, Dwindling Resources, Alienated Youths the Anatomy of Protracted Violence in Sierra Leone.” International Politics and Society, 2003, 2.

Keen, D. Conflict and Collusion in Sierra Leone. New York, NY: Palgrave, 2005. 
Kelsall, T. “Truth, Lies, Ritual: Preliminary Reflections on the Truth and Reconciliation Commission in Sierra Leone.” Human Rights Quarterly. 2005, 27 (2), 361-391.

King, D. “Parallel Routes to Recovery: Community Priorities and NGO Policy in the Post Civil War Reconstruction of Sierra Leone.” International Journal of Emergency Management, 2005, 2(3), 149-153.

Masin-Peters, J. Conflict Diamonds. University of Hampshire, 2003. Retrieved from http://pawss.hampshire.edu/topics/conflictdiamonds/index.html.

McIntyre Miller, W. “Moving Forward in Sierra Leone: Community-Based Factors for Postconflict Development.” Community Development: Journal of the Community Development Society, 2012, forthcoming.

Millar, G. "Between Western theory and Local Practice: Cultural Impediments to Truthtelling in Sierra Leone.” Conflict Resolution Quarterly, 2011, 29 (2), 177-199.

Mundy, L. “The Role of Traditional Ritual in Peacebuilding: With Examples from Sierra Leone and Israel-Palestine.” Unpublished master’s thesis, Bradford University, Bradford, UK, 2005.

Murray, S, and McKague, K. YouthWORKS Microfranchising Project Evaluation. United Nations Development Program, Freetown Sierra, Leone, 2010.

National Recovery Committee. Sierra Leone: Recovery Strategy for Newly Accessible Areas. 2002. Retrieved from http://www.brookings.edu/projects/idp/Laws-andPolicies/ /media/Files/Projects/IDP/Laws\%20and\%20Policies/Sierra_Leone/SierraLeone _RecoveryStrategy_2002.pdf

Parringer, E. African Traditional Religion. New York: Greenwood Press, 1976. 
Peake, G., Gormley-Heenan, C., and Fitzduff, M. From Warlords to Peacelords: Local Leadership Capacity in Peace Processes. Londonderry, INCORE Report, University of Ulster, 2004.

Pham, J. P. The Sierra Leone Tragedy: History and Global Dimensions. New York, NY: Nova Science Publishers, Inc, 2006.

Richards, P. “To Fight or to Farm? Agrarian Dimensions of the Mano River Conflict (Liberia and Sierra Leone).” African Affairs, 2005. 104(417), 571-590.

Richards, P., Bah, K., and Vincent, J. "Social Capital and Survival: Prospects for CommunityDriven Development in Post-Conflict Sierra Leone.” 2004. Retrieved from the World Bank website: http://www-wds.worldbank.org/servlet/WDSContentServer/ WDSP/IB/2004/04/16/000012009_20040416142448/Rendered/PDF/28561.pdf

Sawyer, E. "Remove or Reform? A Case for (Restructuring) Chiefdom Governance in PostConflict Sierra Leone.” African Affairs, 2008, 107(428), 387-403.

Thomson, B. Sierra Leone: Reform or Relapse? Conflict and Governance Reform. London, United Kingdom: Chatham House, 2007.

Writenet. Sierra Leone: From cease-fire to lasting peace? United Nations High Commission for Refugees, 1997. Retrieved from http://www.unhcr.org/refworld/ country,,WRITENET,,SLE,456d621e2,3ae6a6b624,0.html

Whitney McIntyre Miller, Ph.D., is trained in leadership studies, international development, and social work and is an Assistant Professor of Organizational Leadership at Northern Kentucky University. She focuses her work primarily on leadership for community development, with a particular emphasis on postconflict societies. 